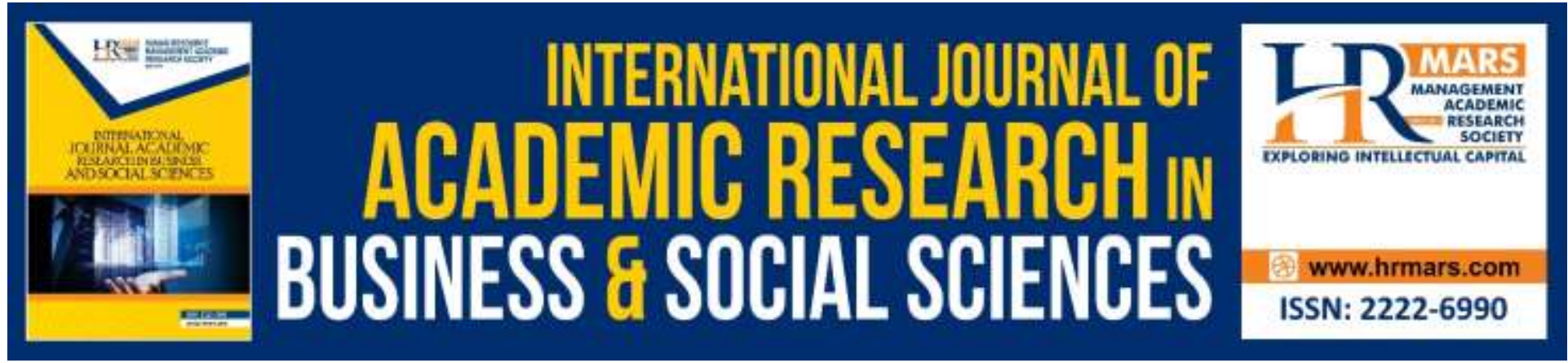

\title{
Phenomenological Case Study of Spiritual Connectedness in the Academic Workplace
}

\section{Zaireena Wan Nasir}

To Link this Article: http://dx.doi.org/10.6007/IJARBSS/v9-i9/6410

DOI: $10.6007 /$ IJARBSS/v9-i9/6410

Received: 10 July 2019, Revised: 09 August 2019, Accepted: 30 August 2019

Published Online: 26 September 2019

In-Text Citation: (Nasir, 2019)

To Cite this Article: Nasir, Z. W. (2019). Phenomenological Case Study of Spiritual Connectedness in the Academic Workplace. International Journal of Academic Research in Business and Social Sciences, 9(9), 1156-1165.

Copyright: @ 2019 The Author(s)

Published by Human Resource Management Academic Research Society (www.hrmars.com)

This article is published under the Creative Commons Attribution (CC BY 4.0) license. Anyone may reproduce, distribute, translate and create derivative works of this article (for both commercial and non-commercial purposes), subject to full attribution to the original publication and authors. The full terms of this license may be seen at: http://creativecommons.org/licences/by/4.0/legalcode

Vol. 9, No. 9, 2019, Pg. 1156 - 1165

Full Terms \& Conditions of access and use can be found at http://hrmars.com/index.php/pages/detail/publication-ethics 


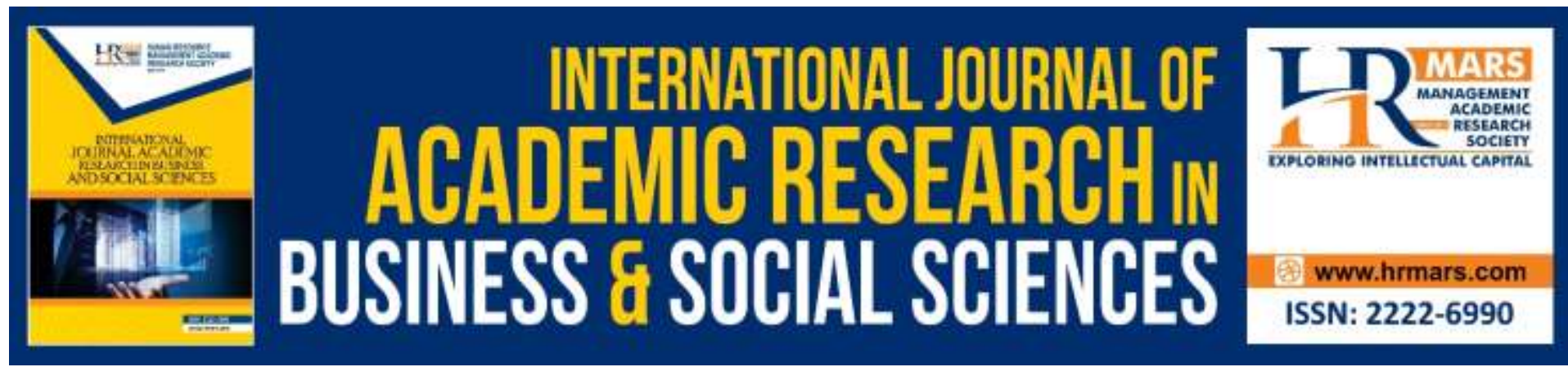

\title{
Phenomenological Case Study of Spiritual Connectedness in the Academic Workplace
}

\author{
Zaireena Wan Nasir \\ International Islamic University Malaysia, Malaysia
}

\begin{abstract}
The field of workplace spirituality is plagued by problems of definition due to the ambiguity of the term "spirituality" from the Western perspective. As workplace spirituality is by nature an ephemeral phenomenon approachable from multiple perspectives, this study approaches this topic from the Islamic perspective. The inductive research method chosen is a combination of phenomenology and qualitative case study. Phenomenology is chosen as it describes the meaning for individuals of their lived experiences of a phenomenon. The International Islamic University of Malaysia is chosen as the case study due to its prominence as a premier global Islamic university. In-depth interviews with academics, both local and international, of the International Islamic University of Malaysia are the primary method of data collection. Thirteen academics, six males and seven females, from this university have been interviewed for this purpose. Findings suggest that spiritual connectedness is about the relationship with Allah and the relationship with human beings (habluminallah wa habluminannas), God consciousness (taqwa), sense of belonging, doing for the sake of Allah, brotherhood (ukhuwwah), inviting towards what is good and forbidding from wrong (amar ma'ruf nahi mungkar) and ihsan. The implication of these findings highlights the understanding of Muslim academics of what being spiritually connected mean to them personally. The contribution of this study is to enrich the literature on workplace spirituality by exploring the Islamic perspective of spiritual connectedness and to understand first-hand how being spiritually connected is defined by Muslim academics.
\end{abstract}

Keywords: Spiritual Connectedness, Workplace Spirituality, Islamic Perspective, Academic Workplace, Organizational Behavior

\section{Introduction}

I first came across the term "workplace spirituality" in an Organizational Behavior textbook by Robbins and Judge (2007). This course was taught by me, as a lecturer in the Department of Business Administration, in the Faculty of Economics and Management Sciences, of the International Islamic University of Malaysia (IIUM). In the textbook by Robbins and Judge (2007: 530), there was a statement made that spirituality and religiosity are two different things: "Workplace spirituality is not about organized religious practices. It's not about God or theology." This goes against my beliefs as a Muslim which is that there is no 
separation between spirituality and religiosity, and so I was driven to present the Islamic point of view.

The field of workplace spirituality is plagued by problems of definition due to the ambiguity of the term "spirituality" from the Western perspective. As workplace spirituality is by nature an ephemeral phenomenon approachable from multiple perspectives, this study approaches the topic from the Islamic perspective.

Workplace spirituality is an area of study, for my research I will be focusing on spiritual connectedness as the construct of my study. Connectedness was described by Vachon et al. (2009: 55) as a feeling of communion in which the person has relationships that are intrapersonal and interpersonal and "implies a feeling of not being alone." Worthington and Aten (2009) spoke about spirituality as a feeling of closeness and connection to a higher power, humankind, nature and the cosmos. The concept of connection in spirituality is a feeling of not being alone involving a wholeness which may mean being related to oneself, others and the universe (Florczak, 2010; Ahmed, Khalid, Ammar, \& Shah, 2017).

In the Islamic perspective, the working life for a Muslim is not secular where there is separation between working towards worldly pursuits and working towards the Hereafter. Work is a form of ibadah or worship. In a Muslim's life, there is one's relationship to Allah (habluminallah) and one's relationship to people (habluminannas) that governs one's daily activities. On spirituality, Al-Zeera (2001: 12-13) wrote that it is an inner feeling that cannot be proven by facts or reason. When the soul is given the right surroundings in which to grow and experience its sacredness, the person who treasures the soul inwardly becomes spiritual. Religiosity can be a public matter, but not spirituality. The difference between the two is that religious rituals are only a manifestation of a deeper level of inner realization. Therefore, a Muslim's spirituality is rooted in religion. Being religious and spiritual means being virtuous and ethical in following God's guidance (Zeera, 2017). In a Muslim's daily prayers (solat) is recited, "Verily my prayers, my worship, my life and my death is solely for Allah."

This study explores in-depth how being spiritually connected is manifested in the academic workplace. The International Islamic University of Malaysia (IIUM) was established in 1983 with the philosophy that knowledge shall be propagated in the spirit of Tawhid, leading towards the recognition of Allah as the Absolute Creator and Master of mankind. Its vision is to become a leading center of educational excellence which seeks to restore the dynamic and progressive role of the Muslim Ummah in all branches of knowledge and intellectual discourse. However, little is known of the state of spiritual connectedness of academics in the IIUM. The specific objective of this study is to analyse the meaning of spiritual connectedness among Muslim academics in IIUM.

Despite an increasing focus on spirituality in the psychological literature, Aten and Hernandez (2005) note that only a small number of empirical publications used a qualitative method, the majority being either quantitative or theoretical. Based on their 25-year review of qualitative research published in spiritually and psychologically oriented journals, Aten and Hernandez (2005: 274) suggest that qualitative studies help researchers to gain a better understanding of how participants make meaning in their lives and how this impacts spiritual well-being. 


\section{Literature Review}

The research objective posed in this study touch upon several primary areas of scholarship: literature on workplace spirituality (WPS), and literature on spiritual connectedness in the academic workplace. I will present a review of the literature in these areas that are most relevant to my study. The field of my study on spiritual connectedness in the workplace lies within the area of workplace spirituality. Giacalone and Jurkiewicz who were the editors of the Handbook of Workplace Spirituality and Organizational Performance (2003) defined workplace spirituality as "a framework of organizational values evidenced in the culture that promotes employees' experience of transcendence through the work process, facilitating their sense of being connected to others in a way that provides feelings of completeness and joy" (p.13). Workplace spirituality could also be understood within a holistic context to be a system of interwoven cultural and personal values and changes that impact all aspects of life, including organizational life (Giacalone \& Jurkiewicz 2003: 14-15).

According to Neck and Milliman (1994); Ahmed, Majid, \& Zin, (2016) a central aspect of spirituality involves the meaning of one's work, something which an increasing number of employees are striving to attain (Hawley 1993). One philosophical viewpoint suggests that work is intended to be one of the most profound ways of experiencing the divine presence in the world, that is, of experiencing spirituality (Holland 1989). The nature of an individual's work (e.g. spiritual or non-spiritual) may depend largely on how one views it. An individual's attitude toward his/her work is a primary factor toward his/her work becoming a spiritual process (Dale 1991). Dale (1991: 5) defines spirituality as that human striving for the transforming power present in life; "it is that attraction and movement of the human person toward the divine." A common theme is that workplace spirituality is expressing our desires to find meaning and purpose in our lives and is a process of living out one's set of deeply held personal values (Block 1993, Ray 1992). These values often reflect a desire to make a difference and create a meaningful world (Ray 1992). All individuals are seen as having the potential to be spiritual, which includes an inner wisdom, authority (Ray 1992), and compassion (Maynard 1992).

Mitroff and Denton (1999a) studied spirituality in the American workplace. Spirituality as defined by Mitroff and Denton (1999a: 83) is "the basic feeling of being connected with one's complete self, others and the entire universe." Mitroff and Denton's study (1999b) found that $60 \%$ of the respondents had positive views of spirituality while the rest had negative views of religion. Spirituality is a multidimensional idea but one with a unified core meaning: the presence of a supreme, transcendent force that defines purpose in human affairs; an acceptance that each person is linked to all others in society, nature, and the world; a sacredness and sense of awe toward all creations; and a source of inner peace, faith, and willpower when facing difficult situations. Managers agreed almost unanimously on the importance of finding "ultimate meaning and purpose in one's life," which was for them the outcome of a desired spiritual quest. Most managers, for the most part, believe religious doctrines to be highly inappropriate for business life, citing them as dogmatic, intolerant, and divisive.

Milliman, Czaplewski and Ferguson (2003) consider the meaning and implications of spirituality within the context of the workplace. While WPS is considered a highly personal 
and philosophical construct, nearly all academic definitions acknowledge that spirituality involves a sense of wholeness, connectedness at work, and deeper values (Gibbons 2000). WPS involves the effort to find one's ultimate purpose in life, to develop a strong connection to co-workers and other people associated with work, and to have consistency (or alignment) between one's core beliefs and the values of their organization (Mitroff \& Denton 1999b). WPS can also be defined as "...the recognition that employees have an inner life that nourishes and is nourished by meaningful work that takes place in the context of the community" (Ashmos \& Duchon, 2000: 137).

According to Singhal and Chatterjee (2006), there seems to be as many definitions of WPS as there are researchers. The definitional multiplicity owes itself to the highly subjective nature of WPS as a concept, with many scholars claiming that trying to define it before initiating research forces a straitjacket the phenomenon itself does not allow (Dean, 2004). Mitroff and Denton (1999b) argues, "An "obsession" with finding a single correct, overarching definition of WPS does not respect the myriad traditions and belief systems embedded in our research arena." The issue of defining spirituality thus comes across as major stumbling block in the empirical examination of issues relating to WPS. While there are those who argue that the essential subjectivity of WPS makes a single definition impossible (Gull \& Doh, 2004), others argue that the concept of organizational spirituality "is not so much elusive and intangible as confused and imprecise" (Brown 2003: 393). Further, a section of scholars argue that not defining WPS makes it impossible to compare the findings from different studies (Giacalone \& Jurkiewicz, 2003), a step necessary for theoretical advancement. In between these two diametrically opposite perspectives, a central position is indicated with the suggestion for identification of a few central themes from literature as a starting point and then building it up with inputs from empirical enquiry (Dean 2004, Dean, Fornaciari \& McGee, 2003). Another recommendation postulates spirituality as a multidimensional construct (Hill, Pargament, Hood, McCullough, Swyers, Larson \& Zinnbauer 2000, Milliman, Czaplewski and Ferguson 2003), and recommends a profile analysis of each element individually - and all elements collectively - as a fruitful way of studying the phenomenon.

A study, by Bradley and Kauanui (2003), examined the spirituality of professors and the spiritual culture found in a private secular college, a private Christian college and a state university, all located in southern California. The design of the research was based on the work of Mitroff and Denton (1999b), and Palmer (1998). The results showed that there was a difference in the spiritual culture between these three campuses and that spirituality of the professors was a reflection of the spiritual culture found on the campuses. Parker J. Palmer is a pioneer in the movement of spirituality in academia. His book, The Courage to Teach and conferences by the same title build on the idea that "good teaching cannot be reduced to technique; but comes from the identity and integrity of the teacher (Palmer 1998: 10). Palmer (1998: 4) commented that the development of the intellect, emotion and spirit are crucial to good teaching; that teaching only with the intellect leaves the subject cold, unreal; teaching only with the emotions becomes an exercise in arrogance; and teaching only with the spirit makes the subject "other worldly", without anything concrete in the real world.

The study by Bradley and Kauanui (2003: 451) modified Boje's (2000) study to arrive at definitions of spirituality to be chosen by the professors in the survey. Five paradigms were 
used to define spirituality: traditionalist, cultist, humanist, affirmative postmodern and sceptical postmodern. 112 usable surveys were returned giving a response rate of 17 percent. Both private secular college and private Christian college chose the first category, "traditionalist", that is belonging to a world or major religion, as their first choice and "humanist", that is to define spirituality in terms of self-development, compassion, honesty and other terms of relationship and value towards others, as their second choice. The state university had the same choices but in reverse order (p.458).

\section{Research Method}

The inductive research method chosen in this study is a combination of phenomenology and qualitative case study. These two different designs are combined as the case study method studies one particular case and the approach of phenomenology suits the topic of study, spiritual connectedness. The International Islamic University of Malaysia is chosen as the case study due to its prominence as a premier global Islamic university and it is the first Islamic university established in Malaysia. In-depth interviews with academics, both local and international, of IIUM are the primary method of data collection. Thirteen academics, six males and seven females, from this university have been interviewed for this purpose. Documents analysis is used as a secondary method of data collection. The unit of analysis is individual as the experience of individual Muslim academics are explored for the essence of their spiritual connectedness. The findings were analyzed using Moustaka's approach of phenomenology.

The type of phenomenology I have chosen is the empirical, transcendental, or psychological phenomenology by Moustakas (1994). It is focused less on the interpretations of the researcher and more on a description of the experiences of participants. Moustakas (1994) focuses on epoche (or bracketing), in which investigators set aside their experiences, as much as possible, to take a fresh perspective toward the phenomenon under investigation. "Transcendental" means "in which everything is perceived freshly, as if for the first time" (Moustakas 1994: 34). Moustakas (1994) admits that this state is seldom perfectly achieved. Researchers embrace this idea when they begin a project by describing their own experiences with the phenomenon and bracketing out their views before proceeding with the experiences of others. 
Table 1. Theoretical framework, study purpose and case selection criteria

\begin{tabular}{|c|c|c|c|}
\hline Title of Study & $\begin{array}{l}\text { Theoretical } \\
\text { Framework }\end{array}$ & $\begin{array}{l}\text { Study } \\
\text { Purpose }\end{array}$ & $\begin{array}{c}\text { Case Selection } \\
\text { Criteria }\end{array}$ \\
\hline $\begin{array}{l}\quad \text { A } \\
\text { phenomenological } \\
\text { case study of } \\
\text { spiritual } \\
\text { connectedness in } \\
\text { the academic } \\
\text { workplace }\end{array}$ & $\begin{array}{l}\text { - Spiritual } \\
\text { connectedness } \\
\text { - The academic } \\
\text { workplace }\end{array}$ & $\begin{array}{l}\text { To } \\
\text { understand } \\
\text { how being } \\
\text { spiritually } \\
\text { connected is } \\
\text { manifested in } \\
\text { the academic } \\
\text { workplace }\end{array}$ & $\begin{array}{l}\text { - Academic } \\
\text { staff of IIUM } \\
\text { - Employed } \\
\text { more than a } \\
\text { year } \\
\text { - Muslims } \\
\text { - Have } \\
\text { experienced } \\
\text { the } \\
\text { phenomenon }\end{array}$ \\
\hline
\end{tabular}

\section{Findings}

Epoche is the first step of the phenomenological reduction process. It is an approach taken at the beginning of the study by the researcher so that she can set aside her views of the phenomenon and focus on those views reported by the participants. According to Moustakas (1994: 85), epoche is "an experience in itself, a process of setting aside predilections, prejudices, predispositions, and allowing things, events, and people to enter anew into consciousness, and to look and see them again, as if for the first time." The first step in the analysis is the process of horizonalization in which specific statements are identified in the transcripts that provide information about the experiences of the participants. These significant statements are simply gleaned from the transcripts and documents.

Seven themes were found. The themes suggest that spiritual connectedness is about the relationship with Allah and the relationship with human beings (habluminallah wa habluminannas), God consciousness (taqwa), sense of belonging, doing for the sake of Allah, brotherhood (ukhuwwah), inviting towards what is good and forbidding from wrong (amar ma'ruf nahi mungkar) and ihsan. The textural and structural descriptions of the experience are synthesized into a composite description of the phenomenon through the research process referred to by Moustakas (1994: 100) as intuitive integration. This description becomes the essential invariant structure of ultimate essence which captures the meaning ascribed to the experience of spiritual connectedness in the workplace. The description below describes the essence of the experience:

Spiritual connectedness in the workplace begins with a Muslim academic who sees work as ibadah, that is, a form of worship. The interpersonal relationship with others or habluminannas is juxtaposed with the intrapersonal relationship with Allah or habluminallah. Taqwa defines what spiritual connectedness is about while tawhid underlies the connection to all. The essence of the experience is iman which is the foundation of a Muslim's belief. 


\section{Conclusion}

The implication of these findings highlights the understanding of Muslim academics of what being spiritually connected mean to them personally. My findings of outcomes of spiritual connectedness of Muslim academics largely differ from the literature due to my participants' view of spiritual connectedness from an Islamic perspective. Therefore their opinions on the outcomes of being spiritually connected come from an Islamic paradigm. The implication of my findings on managerial practices relates to Islamic human resources practices which emphasizes that work is ibadah (worship). The niat (intention) for work is for Allah (lillahitaala). Allah is the ultimate in giving rewards. There is no separation between this world and the Hereafter, and that the Muslim worker is given space for ibadah that is specific (khusus) and general (umum). Islamic human resource practices is performing the major human resource functions in accordance to guidelines stated in al-Qur'an and Hadith and these functions include recruitment, selection, performance appraisal, training and development, and compensation. The contribution of this study is to enrich the literature on workplace spirituality by exploring the Islamic perspective of spiritual connectedness and to understand first-hand how being spiritually connected is defined by Muslim academics.

\section{Corresponding Author}

Zaireena Wan Nasir

Department of Business Administration

Kulliyyah of Economics and Management Sciences

International Islamic University Malaysia

PO Box 10, 50728 Kuala Lumpur, Malaysia

Email: zaireena@iium.edu.my

\section{References}

Ahmed, U., Khalid, N., Ammar, A., \& Shah, M. H. (2017). Assessing moderation of employee engagement on the relationship between work discretion, job clarity and business performance in the banking sector of Pakistan. Asian Economic and Financial Review, 7(12), 1197-121.

Ahmed, U., Majid, A. H. A., \& Zin, M. M. (2016). Moderation of meaningful work on the relationship of supervisor support and coworker support with work engagement. The Journal of Business, Economics, and Environmental Studies (JBEES), 6(3), 15-20

Al Zeera, Z. (2001). Wholeness and Holiness in Education: An Islamic Perspective. Herndon, VA: The International Institute of Islamic Thought.

Ashmos, D. R. \& Duchon, D. (2000). Spirituality at Work: a conceptualization and measure. Journal of Management Inquiry 9(2): 134-145.

Aten, J. D. \& Hernandez, B. C. (2005). A 25-Year review of qualitative research published in spiritually and psychologically oriented journals. Journal of Psychology and Christianity 24(3): 266-277.

Block, P. (1993). Stewardship: Choosing Service over Self-interest. San Francisco: BerretKoehler Publishers.

Boje, D. (2000). Another view: approaches to the study of spiritual capitalism. In Biberman, J. \& Whitty, M. D. (ed.). Work and Spirit: A Reader of New Spiritual Paradigms for Organizations, pp. xxv-xxxii. Scranton: The University of Scranton Press. 
Bradley, J. and Kauanui, S. K. (2003). Comparing spirituality on three southern California college campuses. Journal of Organizational Change Management 16(4): 448-462.

Brown, R. B. (2003). Organizational Spirituality: The Sceptic's Version. Organization 10(2): 393-400.

Dale, E. S. (1991). Bringing Heaven down to Earth: A Practical Spirituality of Work. New York: Peter Lang.

Dean, K. L. (2004). Systems Thinking's Challenge to Research in Spirituality and Religion at Work: An Interview with Ian Mitroff. Journal of Organizational Change Management 17(1): 11-25.

Dean, K. L. Fornaciari, C. J. \& McGee, J. J. (2003). Research in Spirituality, Religion, and Work: Walking the Line between Relevance and Legitimacy. Journal of Organizational Change Management 16(4): 378-395.

Florczak, K. L. (2010). Gathering information on spirituality: From whose perspective? Nursing Science Quarterly 23(3): 201-205.

Giacalone, R. A. \& Jurkiewicz, C. L. (ed.). (2003). Handbook of Workplace Spirituality and Organizational Performance. Armonk, NY: M.E. Sharpe.

Gibbons, P. (2000). Spirituality at work: Definitions, measures, assumptions, and validity claims. Paper presented at the Academy of Management, Toronto.

Gull, G. A. \& Doh, J. (2004). The "Transmutation" of the Organization: Toward a More Spiritual Workplace. Journal of Management Inquiry 13(2): 128-139.

Hawley, J. (1993). Reawakening the Spirit in Work: The Power of Dharmic Management. San Francisco, CA: Berrett-Koehler Publishers.

Hill, P. C., Pargament, K. I., Hood, R. W., McCullough, M. E., Swyers, J. P., Larson, D. B. \& Zinnbauer, B. J. (2000). Conceptualizing Religion and Spirituality: Points of Commonality, Points of Departure. Journal for the Theory of Social Behavior 30(1): 5177.

Holland, J. (1989). Creative Communion: Toward a Spirituality of Work. New York: Paulist Press.

https://doi.org/10.18488/journal.aefr.2017.712.1197.1210

Maynard, H. B. (1992). The Evolution of Human Consciousness. In Renesch, J. (ed.) New Traditions in Business, pp.39-52. San Francisco, CA: Berrett-Koehler Publishers.

Milliman, J., Czaplewski, A. J., \& Ferguson, J. (2003). Workplace spirituality and employee work attitudes: An exploratory empirical assessment. Journal of Organizational Change Management 16(4): 426-447.

Mitroff, I. \& Denton, E. A. (1999a). A study of spirituality in the workplace. Sloan Management Review, Summer: 83-92.

Mitroff, I. I. \& Denton, E. A. (1999b). A Spiritual Audit of Corporate America: A Hard Look at Spirituality, Religion, and Values in the Workplace. San Francisco, CA: Jossey-Bass Publishers.

Moustakas, C. (1994). Phenomenological research methods. Thousand Oaks, CA: Sage.

Neck, C. P. \& Milliman, J. F. (1994). Thought Self-leadership: Finding Spiritual Fulfilment in Organizational Life. Journal of Managerial Psychology 9(6): 9-16.

Palmer, P. (1998). The courage to teach. San Fransisco, CA: Jossey-Bass.

Ray, M. L. (1992). The Emerging New paradigm in Business. In Renesch, J. (ed.) New Traditions in Business, pp.25-38. San Francisco, CA: Berrett-Koehler Publishers.

Robbins, S. P. \& Judge, T. A. (2007). Organizational Behavior. Pearson Prentice Hall. 
Singhal, M. \& Chatterjee, L. (2006). A Person-Organization Fit-based Approach for Spirituality at Work: Development of a Conceptual Framework. Journal of Human Values 12(2): 161-178.

Vachon, M., Fillion, L. \& Achille, M. (2009). A conceptual analysis of spirituality at the end of life. Journal of Palliative Medicine 12(1): 53-59.

Worthington, E. L. \& Aten, J. D. (2009). Psychotherapy and religious and spiritual clients: An introduction. Journal of Clinical Psychology: In Session 65(2): 123-130. 